\title{
The Role of SV Ion Channels Under the Stress of Mycotoxins Induced in Wheat Cells-Protective Action of Selenium Ions
}

\author{
Mateusz Koselski ${ }^{1} \cdot$ Halina Dziubińska ${ }^{1} \cdot$ Kazimierz Trębacz $^{1} \cdot$ Apolonia Sieprawska² $^{2} \cdot$ Maria Filek $^{2,3}$
}

Received: 29 October 2018 / Accepted: 7 January 2019 / Published online: 11 March 2019

(c) The Author(s) 2019

\begin{abstract}
Mycotoxin stress, one of the currently intensively studied, was stimulated in wheat hypocotyl cells through the application of zearalenone, produced by Fusarium fungi. The differences of reactions in the activation of the SV ion channels between stress-tolerant (Parabola) and sensitive (Raweta) wheat cultivars have been studied by the patch-clamp technique. No impact of zearalenone on SV channel activity was observed in Parabola. However, in the sensitive cultivar, mycotoxin $\left(30 \mu \mathrm{mol} \mathrm{L} \mathrm{L}^{-1}\right)$ evoked a significant decrease in the unitary conductance of the channels-from $22 \pm 0.4 \mathrm{pS}(n=5)$ in the control to $18 \pm 0.5$ $\mathrm{pS}(n=7)$ in zearalenone-treated vacuoles (potential clamped at $100 \mathrm{mV}$ ). A combined treatment of zearalenone and selenium $\left(5 \mu \mathrm{mol} \mathrm{L}{ }^{-1}\right.$ of $\mathrm{Na}_{2} \mathrm{SeO}_{4}$ ) abolished this effect totally, indicating the importance of this element in the defense mechanism of cells under the stress of mycotoxins. The role of differences in the membrane structure between tolerant and sensitive cultivars induced in stress conditions, as one of the main factors in mechanical stability of channels, has been discussed.
\end{abstract}

Keywords Zearalenone stress $\cdot$ Vacuolar channels $\cdot$ Wheat cells $\cdot$ Selenium

\section{Introduction}

The increasing interest in healthy food imposes on farmers and biotechnologists the necessity to study the mechanisms of mycotoxin action to diminish their stressful effects in cells, especially crops. Zearalenone (ZEA) is one of the toxins synthesized during pathogen (Fusarium) infections of crops, and may interact with cell membranes via binding to estrogen receptors as was indicated in animal cells (Kowalska et al. 2018). Being lipophilic, ZEA may also directly interact with membranes, like other sterols, influencing structural and physicochemical changes in lipid mono- and bilayers (Gzyl-Malcher et al. 2017; Hac-Wydro et al. 2007).

Apolonia Sieprawska

apolonia.sieprawska@up.krakow.pl

1 Department of Biophysics, Institute of Biology and Biochemistry, Maria Curie-Sklodowska University, Akademicka 19, 20-033 Lublin, Poland

2 Institute of Biology, Pedagogical University, Podchorążych 2, 30084 Krakow, Poland

3 Franciszek Gorski Institute of Plant Physiology, Polish Academy of Science, Niezapominajek 21, 30239 Krakow, Poland
Thus, the participation of the lipid membrane structure seems to be key in ZEA uptake into cells.

The ZEA presence in cells, at hormonal concentrations, stimulates the flowering induction of plants (BiesagaKościleniak and Filek 2010). However, at higher than hormonal amounts, it may stimulate oxidative stress and generation of oxygen radicals, which result in destruction of biologically important molecules, such as proteins, lipids, and DNA (Filek et al. 2017, 2018). Thus, searching for substances that reduce this toxin accumulation and diminish the biochemical consequences of its action is of special importance. Given their antioxidant properties revealed during various environmental stresses, selenium (Se) ions can protect cells against ZEA effects (Sieprawska et al. 2015; Filek et al. 2017). Moreover, the engagement of Se ions in modification of membrane permeability (Tobiasz et al. 2014) and modulation of the activity of slow-activating vacuolar channels (SV) has been indicated (Dziubińska et al. 2010).

SV channels belong to non-selective cation-permeable channels and are abundant in all vascular plants studied. The activity of SV channels adapts to changes in cytoplasmic and vacuolar $\mathrm{Ca}^{2+}$ concentrations, $\mathrm{pH}$, heavy metals, and many others (van den Wijngaard et al. 2001; Dziubińska et al. 2010; Gutla et al. 2012). The understanding about the structure-function coupling of SV channels is intensively studied 
(Schulze et al. 2011; Jaslan et al. 2016), which resulted in the discovery of the crystal structure (Guo et al. 2016) and gene (TPCl-two-pore channel 1) encoding of the channel protein (Peiter et al. 2005).

The aim of this study was to test (i) the ZEA interaction with SV channels in wheat cells and check whether such reaction is dependent on the potential tolerance of plants to stress action, and (ii) the possibility of Se ions to reduce the ZEA effects. Involvement of steroid-like substances (from the class of brassinosteroids) in regulation of cation channel activity in wheat cells was shown by Straltsova et al. (2015). Therefore, it was expected that zearalenone, with a hydrophobic-hydrophilic structure and physiological properties (incorporation into the membrane structure) similar to brassinosteroids, may also influence the disorder in the activation of ion channels. Demonstration of SV channel reaction after this mycotoxin application into the tested cultivars, and the possibility of their modification by the additional of Se, will provide important data for a more precise description, especially, of the mechanisms involved in the initial stages of the stressful/protective actions of these substances.

\section{Material and Method}

Grains of spring wheat (Triticum aestivum) cultivars: Parabola - tolerant and Raweta—sensitive to oxidative stress were chosen. After sterilization, grains were germinated in Petri dishes in the following solutions: (a) distilled water (control), (b) ZEA $\left(30 \mu \mathrm{mol} \mathrm{L}{ }^{-1}\right)$, (c) ZEA $\left(30 \mu \mathrm{mol} \mathrm{L}^{-1}\right)+\mathrm{Se}$ $\left(5 \mu \mathrm{mol} \mathrm{L}{ }^{-1}\right)$ in a dark room at $24 \pm 1{ }^{\circ} \mathrm{C}$. After 3 days, $10-15 \mathrm{~mm}$ long coleoptiles were excised and designated for testing of vacuolar channel activity.

The vacuoles were isolated according to the method described in detail by Trębacz and Schönknecht et al. (2000). Channel activity was measured by the patch-clamp method in the whole-vacuole and cytoplasm-out configurations. In the cytoplasm-out configuration, the cytoplasm side of the tonoplast was oriented outside the patch pipette. SV channel activities were recorded in symmetrical (in the bath and in the pipette) $100 \mathrm{mmol} \mathrm{L} \mathrm{L}^{-1} \mathrm{Na}^{+}$. To prevent activation of channels different from $\mathrm{SV}$, the recordings were performed in the presence of $\mathrm{Mg}^{2+}$ (suppressor of fast vacuolar (FV) channels) and gluconate as the main anion. The bath medium contained (in mmol L${ }^{-1}$ ) $100 \mathrm{NaGlu}, 2 \mathrm{MgCl}_{2}$, $0.1 \mathrm{CaCl}_{2}$, and $15 \mathrm{Hepes}, \mathrm{pH} 7.2$ (buffered by Tris) and the pipette contained $100 \mathrm{NaGlu}, 2 \mathrm{MgCl}_{2}, 0.1 \mathrm{CaCl}_{2}$, and 15 Mes, pH 5.5 (buffered by Tris). The osmolarity of the pipette and medium was $260 \mathrm{mOsm} \mathrm{kg}^{-1}$, as determined with a cryoscopic osmometer (Osmomat 030; Gonotec, Berlin, Germany). The pipettes were made from borosilicate tubes. $\mathrm{An} \mathrm{Ag} / \mathrm{AgCl}$ reference electrode was made from tubes filled with $100 \mathrm{mmol} \mathrm{L}^{-1} \mathrm{KCl}$ connected with the bath medium
Fig. 1 I Patch clamp recordings of slow-activating vacuolar channel activity recorded in wheat cultivars-Raweta (a, c) and Parabola (b, d). $\mathbf{a}$ and $\mathbf{b}$ Whole-vacuole currents obtained by application of $0.5 \mathrm{~s}$ holding voltage $(0 \mathrm{mV})$, then $3 \mathrm{~s}$ test voltages from 100 to $-80 \mathrm{mV}$ with $20 \mathrm{mV}$ steps and $0.3 \mathrm{~s}$ pulse $(0 \mathrm{mV})$. c and d Cytoplasm-out traces. The values of holding voltages are presented on the left side. Solid lines indicate closed states of the channels and dashed-open states. II Activity of SV channels from the sensitive Raweta (a, $\mathbf{c}$ and e) and the tolerant Parabola (b, $\mathbf{d}$ and $\mathbf{f}$ ) grown in water, ZEA, Se or a ZEA + Se. a and b Cytoplasm-out traces recorded at $+60 \mathrm{mV}$ in Raweta and Parabola, respectively. $\mathbf{c}$ and $\mathbf{d}$ The amplitude histograms obtained from traces presented in $\mathbf{a}$ and $\mathbf{b}$, respectively. The values of the open probability $\left(\mathrm{P}_{\mathrm{O}}\right)$, the number of events (vertical line), and the current amplitude (distances between maxima in the amplitude histograms in $\mathrm{pA}$ ) were indicated. e and $\mathbf{f} \mathrm{I} / \mathrm{V}$ curves (plotted from means \pm standard error) obtained from seedlings cultivated in water (closed circles, $n=5$ for Raweta and $n=6$ for Parabola), ZEA (open circles, $n=7$ for Raweta and $n=5$ for Parabola), Se (closed triangle, $n=6$ for Raweta and $n=4$ for Parabola) and ZEA + Se (open squares, $n=3$ for Raweta and $n=4$ for Parabola)

by a porous tip. The recordings were made by an EPC- 10 amplifier (Heka Electronik, Lambrecht, Germany) which operated with the Patchmaster software (Heka Electronik). The sampling rate was $10 \mathrm{kHz}$ and a $1 \mathrm{kHz}$ filter was used. The results were presented according to the convention proposed by Bertl et al. (1992). The number of repeats " $n$ " denote the number of vacuole patches tested.

\section{Results and Discussion}

Under the conditions used in our study, whole-vacuole currents typical for the SV channel were recorded. The characteristic for the currents was slow activation observed at positive voltages and virtual lack of negative currents (Fig. 1 Ia and b). The cytoplasm-out recordings showed similar conductance of SV channels in both genotypes tested. The values of this parameter obtained at $100 \mathrm{mV}$ reached $22 \pm 0.4$ pS, $n=5$ (Fig. 1 IIe) for Raweta and $19.5 \pm 0.3 \mathrm{pS}, n=6$ (Fig. 1 IIf) for Parabola. The similarity was also found in the open probability which at $60 \mathrm{mV}$ reached 0.16 for Raweta (Fig. 1 IIc upper panel) and 0.11 for Parabola (Fig. 1 IId upper panel). Current/voltage, I/V curves obtained from single channel analysis of both cultivars were not linear and displayed inward rectification typical for single SV channel recordings (Fig. 1 IIe and IIf).

Obvious effects of ZEA were recorded in Raweta, because SV channels possessed lower conductance than those of seedlings cultivated in distilled water (Fig. 1 II). A decrease in the conductance was confirmed from the amplitude histograms (Fig. 1 IIc) and from I/V curves (Fig. 1 IIe). The differences in the conductance increased together with positive voltages applied and the maximal reduction of this parameter (to $18 \pm 0.5 \mathrm{pS}, n=7$ ) was recorded at $100 \mathrm{mV}$ (Fig. 1 IIe). The effects were not observed in Parabola (Fig. 1 IIf). 


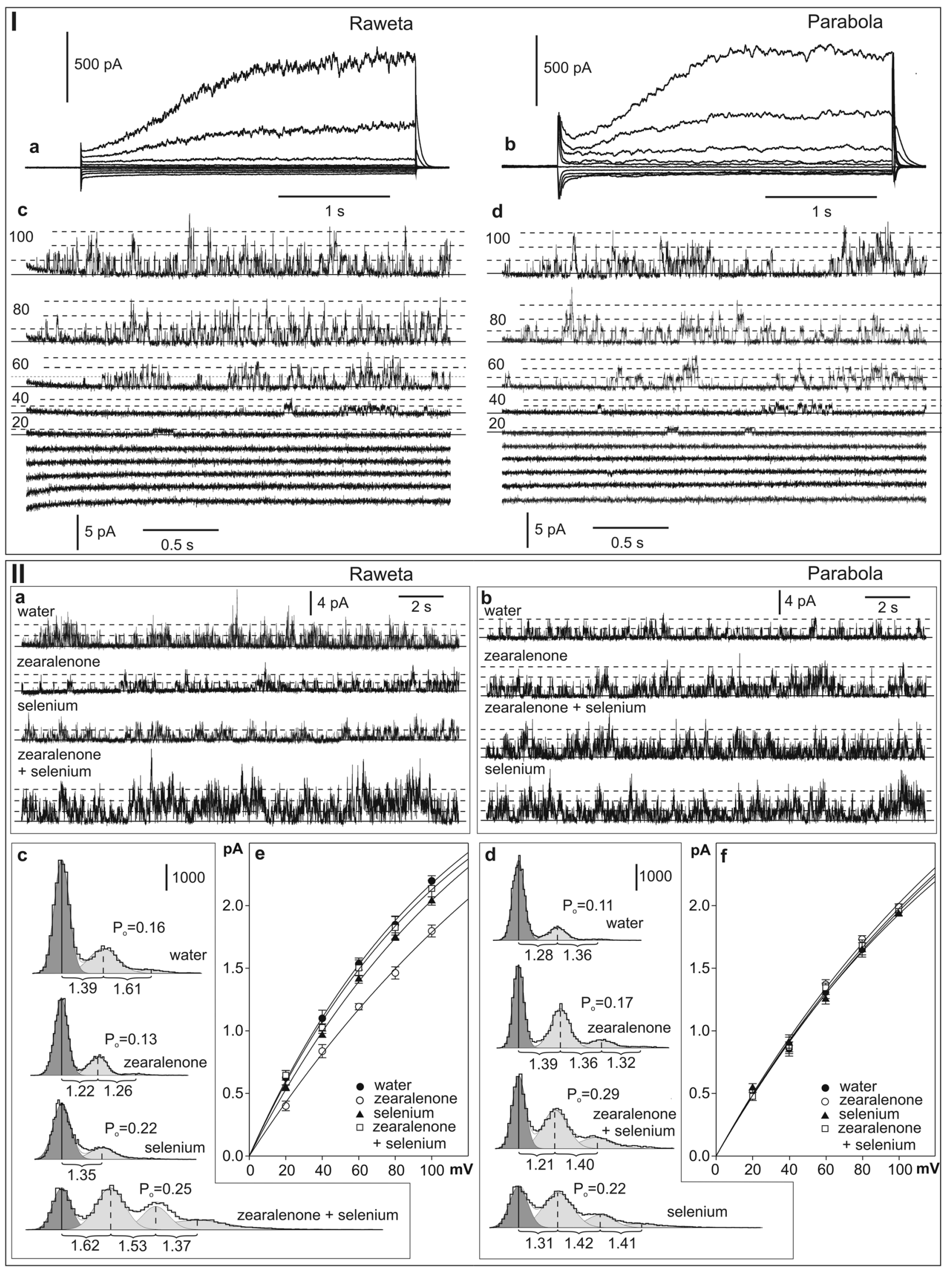


For ZEA+Se treated objects, the decrease in the conductance of SV channels registered for Raweta in ZEA presence was abolished by Se (Fig. 1 IIa, c and e). The values of this parameter recorded in seedlings cultivated in the presence of Se together with ZEA were similar to controls. For instance, at $100 \mathrm{mV}$, the conductance of SV channels was only slightly reduced to $21.4 \pm 0.7 \mathrm{pS}$.

Interestingly, in the presence of selenium alone, a slight decrease in SV channel conductance was recorded in Raweta (the value of this parameter at $100 \mathrm{mV}$ reached $20.4 \pm 0.3$ $\mathrm{pS}, n=6$; see Fig. 1 IIe). It seems that the reduction of the ZEA effect after the application of selenium is not a result of the difference between conductance values recorded after selenium and ZEA applied alone. In other words, the effects of selenium and ZEA are not synergistic. The slight decrease in the channel conductance after selenium can be compared to the results obtained in rape (Brassica napus) by Dziubińska et al. (2010). In the work by Dziubińska et al. (2010), the examples of single SV current traces indicate reduction of channel conductance by selenium at positive voltages (Fig. 1).

The results presented in this study clearly demonstrate that ZEA differentially affects SV ion channels in vacuoles of tested wheat cultivars, caused a significant decrease in the ion channel conductance only of the sensitive one and that this change was reversed by Se. This is the first indication of the role of these channels in the stress mycotoxin mechanism of the sensitive genotypes. Actually, there is no possibility to compare sequences of TPC 1 genes of the two wheat cultivars because they are not yet deposited in public databases. Thus, one can assume that the differences in SV channel activity observed in the wheat cultivars stem from different regulation mechanisms upstream of SV channels located in the tonoplast or from ZEA-presence modification of lipid structure of tonoplast membranes. Presumably, the differences in the structure of the lipid bilayer between the sensitive and tolerant variety (Filek et al. 2012) are the reasons for various reactions in the activation of channels under the influence of ZEA. The presence of more unsaturated fatty acids in the membranes of Raweta, in comparison to Parabola, can favor the localization of ZEA in the hydrophobic-hydrophilic layer, influencing the limitation of mobility of proteins located in them and mechanical blocking of the activity of channels. Moreover, SV channels may be inhibited by $\mathrm{H}_{2} \mathrm{O}_{2}$ (Pottosin et al. 2009) generated under ZEA-stimulated oxidative stress (Filek et al. 2017). Thus, the observed result-reduction in the unitary conductance in sensitive Raweta genotype-might be explained by the involvement of reactive oxygen species (ROS) in SV regulation. This is corroborated by the impact of Se, which has antioxidant properties (Dziubińska et al. 2010; Sieprawska et al. 2015; Filek et al. 2017). Recently, an interplay between ROS, $\mathrm{Ca}^{2+}$ and SV/TPC1 channels was demonstrated in long-distance signal transmission (Kiep et al. 2015; Gilroy et al. 2016). This, rather unexpected, role of SV channels is so far the best-documented function of these channels in plant physiology.

Acknowledgements This work was supported as part of a project of the National Center of Science (NCN) Poland No. 2014/15/B/NZ9/02192.

\section{Compliance with Ethical Standards}

Conflict of interest No potential conflict of interest was reported by the authors.

Open Access This article is distributed under the terms of the Creative Commons Attribution 4.0 International License (http://creativeco mmons.org/licenses/by/4.0/), which permits unrestricted use, distribution, and reproduction in any medium, provided you give appropriate credit to the original author(s) and the source, provide a link to the Creative Commons license, and indicate if changes were made.

\section{References}

Bertl A, Blumwald E, Coronado R, Eisenberg R, Findlay G, Gradmann D, Hille B, Kohler K, Kolb HA, Macrobbie E, Meissner G, Miller C, Neher E, Palade P, Pantoja O, Sanders D, Schroeder J, Slayman C, Spanswick R, Walker A, Williams A (1992) Electrical measurements on endomembranes. Science 258:873-874

Biesaga-Kościelniak J, Filek M (2010) Occurrence and physiology of zearalenon as a new plant hormone. In: Lichtfouse E (ed) Sociology, organic farming climate change and soil science, vol 3. Springer, Dordrecht, pp 419-435

Dziubińska H, Filek M, Krol E, Trebacz K (2010) Cadmium and selenium modulate slow vacuolar channels in rape (Brassica napus) vacuoles. J Plant Physiol 167:1566-1570. https://doi. org/10.1016/j.jplph.2010.06.016

Filek M, Walas S, Mrowiec H, Rudolphi-Skórska E, Sieprawska A, Biesaga-Kościelniak J (2012) Membrane permeability and microand macroelement accumulation in spring wheat cultivars during the short-term effect of salinity- and PEG-induced water stress. Acta Physiol Plant 34:985-995

Filek M, Łabanowska M, Kurdziel M, Sieprawska A (2017) Electron paramagnetic resonance (EPR) spectroscopy in studies of the protective effects of 24-epibrasinoide and selenium against zearalenone-stimulation of the oxidative stress in germinating grains of wheat. Toxins (Basel) 9:178. https://doi.org/10.3390/ toxins 9060178

Filek M, Sieprawska A, Oklestkova J, Rudolphi-Skórska E, BiesagaKościelniak J, Miszalski Z, Janeczko A (2018) 24-epibrassinolide as a modifier of antioxidant activities and membrane properties of wheat cells in zearalenone stress conditions. J Plant Growth Regul. https://doi.org/10.1007/s00344-018-9792-0

Gilroy S, Bialasek M, Suzuki N, Gorecka M, Devireddy AR, Karpinski S, Mittler R (2016) ROS, calcium, and electric signals: key mediators of rapid systemic signaling in plants. Plant Physiol 171:1606-1615

Guo JT, Zeng WZ, Chen QF, Lee C, Chen LP, Yang Y, Cang CL, Ren DJ, Jiang YX (2016) Structure of the voltage-gated two-pore channel TPC1 from Arabidopsis thaliana. Nature 531(7593):196. https ://doi.org/10.1038/nature16446 
Gutla PVK, Bocaccio A, De Angeli A, Gambale F, Carpaneto A (2012) Modulation of plant TPC channels by polyunsaturated fatty acids. J Exp Bot 63:6187-6197

Gzyl-Malcher B, Filek M, Rudolphi-Skórska E, Sieprawska A (2017) Studies of lipid monolayers prepared from native and model plant membranes in their interaction with zearalenone and its mixture with Selenium ions. J Membr Biol 250:273-284

Hac-Wydro K, Wydro P, Jagoda A, Kapusta J (2007) The study on the interaction between phytosterols and phospholipids in model membranes. Chem Phys Lipids 150:22-34

Jaslan D, Mueller TD, Becker D, Schultz J, Cuin TA, Marten I, Dreyer I, Schönknecht G, Hedrich R (2016) Gating of the two-pore cation channel AtTPC1 in the plant vacuole is based on a single voltage-sensing domain. Plant Biol 18(5):750-760. https://doi. org/10.1111/plb.12478

Kiep V, Vadassery J, Lattke J, Maass J-P, Boland W, Peiter E, Mithöfer A (2015) Systemic cytosolic $\mathrm{Ca}^{2+}$ elevation is activated upon wounding and herbivory in Arabidopsis. New Phytol 207:996-1004

Kowalska K, Habrowska-Górczynska DE, Urbanek KA, Dominska K, Piastowska-Ciesielska AW (2018) Estrogen receptor $\alpha$ is crucial in zearalenone-induced invasion and migration of prostate cancer cells. Toxins 10:98

Peiter E, Maathuis FJM, Mills LN, Knight H, Pelloux J, Hetherington AM, Sanders D (2005) The vacuolar $\mathrm{Ca}^{2+}$-activated channel TPC1 regulates germination and stomatal movement. Nature 434:404408. https://doi.org/10.1038/nature03381
Pottosin I, Wherrett T, Shabala S (2009) SV channels dominate the vacuolar $\mathrm{Ca}^{2+}$ release during intracellular sdignaling. FEBS Lett 583:921-926

Schulze C, Sticht H, Meyerhoff P, Dietrich P (2011) Differential contribution of EF-hands to the $\mathrm{Ca}^{2+}$-dependent activation in the plant two-pore channel TPC1. Plant J 68(3):424-432. https://doi. org/10.1111/j.1365-313X.2011.04697.x

Sieprawska A, Kornaś A, Filek M (2015) Involvement of selenium in protective mechanisms of plants Under environmental stress conditions-review. Acta Biol Cracov Bot 57:9-20

Straltsova D, Chykun P, Subramaniam S, Sosan A, Kolbanov D, Sokolik A, Demidchik V (2015) Cation channels are involved in brassinosteroid signaling in higher plants. Steroids 97:98-106

Tobiasz A, Walas S, Filek M, Mrowiec H, Samsel K, Sieprawska A, Hartikainen H (2014) Effect of selenium on distribution of macro- and micro-elements to different tissues during wheat ontogeny. Biol Plant 58:370-374. https://doi.org/10.1007/s1053 5-014-0407-8

Trębacz K, Schönknecht G (2000) Simple method to isolate vacuoles and protoplasts for patch-clamp experiments. Protoplasma 213:39-45

van den Wijngaard PWJ, Bunney TD, Roobeek I, Schönknecht G, de Boer AH (2001) Slow vacuolar channels from barley mesophyll cells are regulated by 14-3-3 proteins. Febs Lett 488:100-104

Publisher's Note Springer Nature remains neutral with regard to jurisdictional claims in published maps and institutional affiliations. 